prof. zw. dr hab. inż. Ryszard JANIKOWSKI

Wydział Zarządzania, Akademia Wojsk Lądowych

e-mail: ryszard.janikowski@gmail.com

DOI: $10.15290 /$ ose.2017.04.88.01

\title{
ZRÓWNOWAŻONY I ODPOWIEDZIALNY ROZWÓJ A MIASTO MOBILNEJ PRODUKTYWNOŚCI
}

\begin{abstract}
Streszczenie
Celem pracy było pokazanie pewnej koncepcji kształtowania współczesnego miasta w kontekście obecnego etapu rozwoju cywilizacji oraz etapu wdrażania koncepcji zrównoważonego i odpowiedzialnego rozwoju opartego na zintegrowanym i mobilnym podejściu. W teraźniejszości jest to odniesienie się do czwartej rewolucji przemysłowej, stwarzającej nowe kreacyjne możliwości, w tym także (re)kształtowania urbanistyczno-industrialnych ośrodków miejskich. W okresie 2015-2065 prognozuje się wzrost globalnej produktywności od $0,8 \%$ do $1,4 \%$ rocznie jako efekt czwartej rewolucji przemysłowej, czyli wykorzystywania: automatyzacji, digitalizacji i sztucznej inteligencji. Konsekwencje czwartej rewolucji przemysłowej pojawiają się także w przestrzeniach miejskich. Materializuje się tutaj koncepcja miasta 4.0. Wszystko to wpisuje się w kwestie spójności społecznej, gospodarczej i terytorialnej, jak i zrównoważonego i odpowiedzialnego rozwoju, współtworząc ramy polityki spójności lat 2014-2020.
\end{abstract}

Słowa kluczowe: czwarta rewolucja przemysłowa, determinanty polityki spójności, miasto 4.0

\section{SUSTAINABLE AND RESPONSIBLE DEVELOPMENT IN CITIES OF MOBILE PRODUCTIVITY}

\section{Summary}

The purpose of the study is to present a certain concept of shaping a modern city at the current stage of civilizational development and the stage of implementing the concept of sustainable and responsible development based on an integrated and mobile approach. At present, it is the reference to the fourth industrial revolution that has brought new creative possibilities for everything, including (re)shaping urban-industrial city centers. In the period 2015-2065, it is forecast that the increase in global productivity will reach from $0.8 \%$ to $1.4 \%$ a year, as a result of the fourth industrial revolution, the use of automation, digitization, and artificial intelligence. The consequences of the fourth industrial revolution are also noticeable in urban spaces. The concept of town 4.0 is becoming a reality. All this contributes to social, economic and territorial cohesion, as well as to sustainable and responsible development, co-creating the cohesion policy framework for the years 2014-2020.

Key words: fourth industrial revolution, cohesion policy, town 4.0

JEL classification: Q01, O18, L86, 


\section{Wstęp}

Rozwój mobilności zgodnej z zasadami zrównoważonego rozwoju stanowi najważniejsze nyzwanie dla miast praysz̨ości. Mobilność ta obejmuje kilka wymiarón i elementón: zrównoważone, energooszcrędne i tanie systemy komunikacji publicznej; prayjazne środowisko dla takich ekologicznych i beapiecznych sposobów przemieszczania sie, jak rowery i ruch pieszy [Miasta prayszztości..., 2011, s. 44]. Istotna staje się zarazem płaszczyzna mobilności wprost wynikająca z toczącej się właśnie czwartej rewolucji przemysłowej.

Celem pracy jest sformułowanie, w ramach trwającego dyskursu dotyczącego miast przyszłości, miast idealnych czy miast zrównoważonych [Paszkowski, 2011; Miasta przyszłtości..., 2011; Janikowski, 2013], koncepcji kształtowania współczesnego miasta. Uwzględnia się to w kontekście obecnego etapu rozwoju cywilizacji, wdrażania koncepcji zrównoważonego rozwoju opartej na zintegrowanym podejściu, jak również scalaniu: (a) ładu społecznego identyfikującego strategiczne cele i środki oraz przedsięwzięć zmierzających do poprawy jakości życia społeczeństwa; (b) ładu ekonomicznego określającego strategiczne cele i środki generujące efektywny rozwój społeczno-gospodarczy; (c) ładu ekologicznego formułującego uwarunkowania i strategiczne cele korzystania ze środowiska i racjonalnego kształtowania środowiska; (d) ładu przestrzennego wyznaczającego strategiczne cele i kryteria kształtowania struktur przestrzennych; (e) ładu polityczno-instytucjonalnego determinującego pozostałe łady.

$\mathrm{Z}$ jednej strony makroskalowe planowanie przestrzenne jest determinującym czynnikiem kształtowania się zarówno odpowiednich relacji, jak i związków: politycznych, gospodarczych, społecznych czy środowiskowych o strategicznym i systemowym charakterze. $Z$ drugiej strony mikroskalowe planowanie przestrzenne jest determinującym czynnikiem kształtowania się struktur i funkcji przestrzeni miejskich, w tym przestrzeni publicznej. Odnosi się to bezpośrednio do przyszłości miast, które w przeszłości były ośrodkami silnie uprzemysłowionymi, a także dużymi ośrodkami osadniczymi. Jednak w teraźniejszości istota jest odniesienie się do czwartej rewolucji przemysłowej, stwarzającej nowe kreacyjne możliwości, w tym równocześnie (re)kształtowania urbanistyczno-industrialnych ośrodków miejskich.

\section{Rewolucja przemysłowa 4.0}

Każda rewolucja przemysłowa to przełom w procesach wytwarzania, przede wszystkim umożliwiający zwiększenie efektywnego i masowego produkowania dóbr oraz dostarczania usług. Pierwsza rewolucja przemysłowa zaczęła się pod koniec osiemnastego wieku. Wtedy jako siły napędzającej maszyny zaczęto wykorzystywać wodę i parę wodna. Jednocześnie maszyny parowe pozwalały na zwiększone wydobywanie węgla, rud żelaza czy powstanie kolei żelaznej, tym samym tworzyły się ośrodki przemysłowe. W Europie, w umocowaniu do kotwricy weglowej, pojawiły się wielkie zagłębia przemysłowe oraz związane z nimi ośrodki osadnicze, takie jak: Górnośląski Okręg Przemysłowy, Zagłębie Ruhry czy Donieckie Zagłębie Węglowe. Z kolei, na początku dwudziestego wieku nastapiła druga rewolucja przemysłowa, gdy decydującymi czynnikami masowej 
produkcji stały się stal i elektryczność. Kolejna, trzecia rewolucja przemysłowa rozpoczęła się w latach siedemdziesiątych dwudziestego wieku, wtedy w produkcji wytwórczej zaczęto wykorzystywać urządzenia elektroniczne, telekomunikacyjne, ciężkie, stacjonarne roboty przemysłowe, jak również stacjonarne, półprzewodnikowe, komputery, wspierające procesy wytwórcze i usługi.

Czwarta rewolucja przemysłowa miała miejsce na początku pierwszej dekady dwudziestego pierwszego wieku [INDUSTRY 4.0 .., 2014; INDUSTRIE 4.0 .., 2014; Schwab, 2016]. Jako cezurę przyjmuje się rok 2011, wtedy po raz pierwszy tego określenia użył Henning Kagermann [Recommendations for implementing..., 2013]. Nie uzgodniono jeszcze ostatecznej nazwy tego, co krystalizuje się, jednakże używa się tutaj takich określeń, jak: Industry 4.0, inteligentna fabryka, smart przedsiębiorstwo oraz Internet Rzeczy i Usług; Internet Wszystkiego czy Internet Przemysłowy. Przewiduje się, że urzeczywistnienie wizji może zając 10-20 lat, w tym czasie zostanie on-line włączonych/połączonych ponad 50 miliardów urządzeń [Recommendations for implementing..., 2013]. Przy czym nie chodzi tylko o miliardy czy nawet biliony adresowanych rzeczy, raczej konieczne staje się pokonanie, stworzonej przez ludzi dwudziestowiecznej epoki, bariery komunikacyjnej, jaką był/jest protokół komunikacyjny IPv4 o $2^{32}$ adresach, czyli o pojemności około 4 miliardów adresów. Zastąpi/ zastępuje go protokół IPv6 o $2^{128}$ adresach, czyli o niemożliwej do wypowiedzenia liczbie: 340282366920938463463374607 431768211456.

Innymi słowy, po mechanizacji, elektryzacji i automatyzacji pojawiła się cyfryzacja i digitalizacja. Stało się to możliwe przez rozwój: informatycznych systemów komunikowania, mobilnej robotyki, automatyki oraz addytywnego wytwarzania. Nowa formuła działania ludzi, podmiotów gospodarczych/usługowych i podmiotów gospodarstw domowych będzie/jest oparta na bezprzewodowym i przewodowym komunikacyjnym połaczeniu jednoznacznie zaadresowanych (wielu) mobilnych i stacjonarnych smart urządzeń łącznie realizujących i materializujących fizyczny produkt /lub usługe [Janikowski, 2015].

\section{Produktywność}

Ogólna definicja produktywności jest prosta. Jest to stosunek tego, co na wyjściu z systemu, do tego, co na wejściu do systemu, w odniesieniu do danego, wyróżnionego systemu. Przedstawia się to jako równanie:

$$
P=\frac{e f e k t}{\text { nakłady }}
$$

Odpowiednim przykładem tych rozważań jest zakup biletu kolejowego (usługi) na przykład na przejazd z Katowic do Warszawy Centralnej. Obecnie (wersja cyfrowa) wymaga to kilku minut, gdyż korzystając z portali operatora kolejowego InterCity, po wybraniu pożądanej opcji i elektronicznym uiszczeniu zapłaty, na wskazany adres dociera bilet kolejowy. Tam następuje jego wizualizacja i może to być ekran naszego komputera, nasz tablet czy nasz e-zegarek, jak również wydruk na papierze (rysunek 1.). 
RYSUNEK 1.

\section{Wersja fizyczna (zwizualizowana) elektronicznego biletu kolejowego}

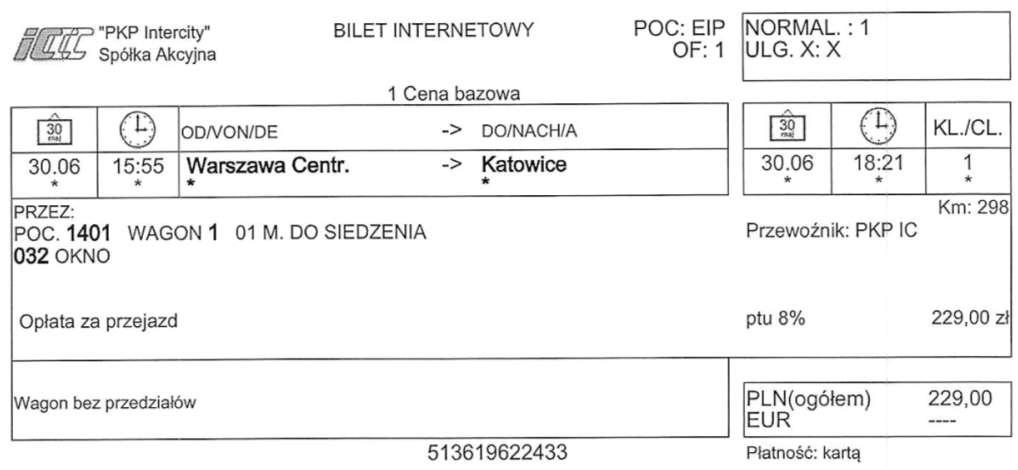

Podróżny: Ryszard Janikowski

Nr transakcji: elC29148353 (ES)0102

Bilet internetowy jest biletem imiennym $\mathrm{i}$ jest ważny:

a) wraz $z$ dokumentem ze zdjęciem potwierdzającym tożsamość Podróżnego,

b) tylko w dniu, relacji, pociągu, wagonie i na miejsce na nim oznaczone.

Zwrotu należności za niewykorzystany bilet dokonuje się na podstawie wniosku złożonego przez płatnika w wyznaczonych przez 'PKP

Intercity ' S.A. punktach, z wyjątkiem należności zwracanych automatycznie na zasadach określonych w Regulaminie e-IC.

Niniejszy bilet internetowy nie jest fakturą VAT.

W związku z przeprowadzanymi modernizacjami sieci kolejowej, uprzejmie prosimy o dokładne sprawdzanie rozkładu jazdy pociągów przed podróżą.

Zapłacono i wystawiono dnia: 2016-06-22 16:31:51 (22313874)

Dokument wygenerowano: 2016-06-22 16:37:00

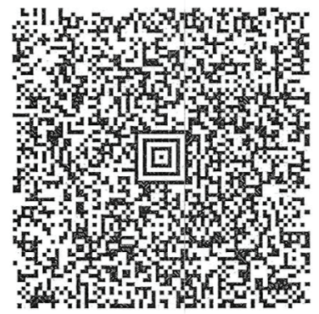

Źródło: bilet internetowy autora.

W przeszłości, a nawet w teraźniejszości, innym sposobem (wersja analogowa) nabycia biletu kolejowego było/jest udanie się na dworzec kolejowy do znajdujących się tam kas. W optymistycznym przypadku zakup biletu trwał łącznie kilkadziesiąt minut, od momentu wyjścia, aż do momentu powrotu z nim. Tym samym relacja między obu produktywnościami cyfrową $P_{\mathrm{c}}$ a analogową $P_{\mathrm{a}}$ jest jednoznaczna:

$$
P_{c}=\frac{\text { bilet kolejowy }}{\text { kilka minut }} \gg P_{a}=\frac{\text { bilet kolejowy }}{\text { kilkadziesiąt minut }} .
$$

Do centrum handlowego można praynieść dużo gotówki, a nawet sztabki złota, ale kupimy szybciej, jeśli skorzystamy z karty keredytowej (badź debetowej) [Ritzera, 2001, s. 69]. Parafrazując, podobnie, do kasy kolejowej można przynieść dużo gotówki, a nawet sztabki złota, ale 
kupimy szybciej i wygodniej, włączając osobisty komputer, laptop czy smartphone. Używając innego języka, bardziej ekonomicznego, jak w analizach McKinsey Global Institute [A Future That Works..., 2017], następuje zwiększanie się globalnej produktywności wraz z zastosowaniem środków i narzędzi każdej kolejnej rewolucji przemysłowej. Ponadto, analizy MGI pokazuja, że w okresie 1850-1910, czyli w czasie pojawiania się efektów pierwszej rewolucji przemysłowej, globalna produktywność związana z wykorzystaniem maszyn parowych wzrastała rocznie o 0,3\%. Z kolei, lata 1993-2007 to wzrost produktywności o $0,4 \%$ rocznie, wynikający ze stosowania wczesnej robotyki w procesach wytwarzania. W latach 1995-2005 czynnik IT (informatyczno-telekomunikacyjny) przyczyniał się do wzrostu produktywności o 0,6\% rocznie. W okresie 2015-2065 MGI prognozuje wzrost globalnej produktywności od $0,8 \%$ do $1,4 \%$ rocznie, jako efekt czwartej rewolucji przemysłowej, czyli wykorzystanie: automatyzacji, digitalizacji i sztucznej inteligencji.

\section{4. Środek twórczy miasta 4.0}

Konsekwencje czwartej rewolucji przemysłowej pojawiają się także w przestrzeniach miejskich. Materializuje się tutaj koncepcja miasta 4.0. Fundamentalnym środkiem twórczym tej kategorii miasta jest sieć internetowa, przy czym istotne jest to, aby była ona szerokopasmowa, o dużych, a nawet bardzo dużych prędkościach dostępu, jak i dostępna w każdym, dowolnym punkcie miasta.

Średnia predkość laczy internetowych w Korei Poludniowej wynosita w III kwartale $2016 \mathrm{r}$. 26,3 Mb/s. Za Korea Potudniowa znalazty się: Hongkong (20,1 Mb/s), Norwegia (20 Mb/s), Szwecja (19,7 Mb/s), Szwajcaria (18,4 Mb/s), Singapur (18,2 Mb/s), Japonia (18 Mb/s), Finlandia $(17,6 \mathrm{Mb} / \mathrm{s})$, Holandia $(17,3 \mathrm{Mb} / \mathrm{s})$ oraz Lotwa $(16,9 \mathrm{Mb} / \mathrm{s})$. Średnia globalna predkośc siegneta 6,3 $\mathrm{Mb} / \mathrm{s}$, co oznacza wrorost o 2,3 proc. wobec poprzedniego kwartatu oraz. o 21 proc. rok do roku. W Polsce średnia predkość szerokopasmowego dostęu do internetu wyniosta w III kwartale 11,7 Mb/s. To o 4,6 proc. mniej niż we wczésniejszych trzech miesiqcach i o 10 proc. wiecej w ujeciu rocznym. Wynike ten daje nam 37. miejsce na swiecie $i 23$. w Europie [http://www.polskaszerokopasmowa.pl/aktualnosci/korea-pld-nie-daje-sie-wyprzedzicw- rankingu-predkosci-laczy-internetowy.html].

Oprócz dużej prędkości szerokopasmowego dostępu do Internetu, sieć ma być przestrzennie, powszechnie (w każdym dowolnym miejscu) dostępna. Oznacza to, że z istoty rzeczy musi być to nie tylko sieć przewodowa, ale i bezprzewodowa. W pierwszym przypadku winna być to sieć światłowodowa ${ }^{1}$, natomiast w drugim sieć mobilna, wykorzystująca: połączenia radiowe, podczerowne, ultradźwiękowe, laserowe lub mikrofalowe. Tym samym dla każdego dowolnego miejsca w mieście może występować dostęp: (1) stacjonarny i połączony przewodowo, (2) stacjonarny i połączony bezprzewodowo, (3) mobilny i bezprzewodowy oraz (4) mobilny i przewodowy. Należy dodać, że system mobilny jest system rozproszonym, złożonym z węzłów połączonych

1 Polska sieć światłowodowa na początku 2017 roku ma długość ponad 100 tys. kilometrów. Jest to wyrażone jako dtugość optyczna. 
siecią komunikacyjna. Od tradycyjnego systemu rozproszonego różni się tym, że użytkownik zmienia swoje położenie, co powoduje ciaggła zmianę topologii sieci.

\section{Miasto $4.0 \mathrm{i}$ wyróżniające go funkcje}

Warunkiem koniecznym do konstytuowania miasta 4.0 lub określanego inaczej jako miasta inteligentne jest jego niematerialna płaszczyzna, jaką musi być płaszczyzna dostępu do sieci w każdym dowolnym, przestrzennym punkcie takiego miasta (ciagłość dostępu). Condicio sine qua non stwarza możliwości zaistnienia nowych funkcji, których nie posiadają dotychczasowe miasta.

Owe nowe funkcje są różnorakie, począwszy od systemów informowania o wolnych miejscach do parkowania w danym zasięgu, poprzez inteligentne oświetlanie chodników dla osób pieszych, aż do systemów optymalnego sterowania światłami drogowymi na skrzyżowaniach dróg. Enumeracja tych funkcji wykracza poza zakres tego opracowania, jednakże gwoli pewnego uzupełnienia należy wskazać dwa przykładowe, mobilne europejskie miasta. Jedno z nich to Amsterdam, miasto posiadające miejską sieć WiFi, która pozwoliła na stworzenie inteligentnego: systemu parkowania, oświetlenia ulicznego i ostrzegawczego oraz sieci elektroenergetycznych. Kolejny przykład to Barcelona, majaca obecnie najnowocześniejszy system komunikacji miejskiej w Europie. W systemie tym istnieja inteligentne przystanki autobusowe wyposażone w: ekrany dotykowe, sieć WiFi i ekrany LCD, na których są wyświetlane informacje. Zebrane przez system informacje służą zmniejszeniu czasu oczekiwania oraz analizie zatłoczenia w środkach komunikacji. Kolejne rozwiazania to inteligentne autobusy wyposażone w: sieć bezprzewodowa, system inteligentnego parkowania oraz oświetlenia drogowego.

Przyszłość miasta i jego nowych funkcji musi być generowana w procesie tworzenia innowacyjnych rozwiązań. Konieczna jest kreacja i wizja przyszłości, w którą są wplecione rozmaite rozwiązania zwiększające jakość życia [Cities of tommorow..., 2011]. Wizja, powstająca jako wyraz wspólnotowego widzenia przyszłości, w sposób formalny materializuje się w ramach instrumentu, jakim jest foresight [Konin 2050, 2015]. Wizja kierunkowana, której celem jest i ma być polepszająca się jakość życia człowieka, rozumiana nie ilościowo, jako co raz większy dobrobyt, a jako zwiększający się stan dobrostanu ludzi.

Oprócz powyższego, niezbędne będzie zarówno wdrażanie technologii całkowicie wykorzystujących skutki czwartej rewolucji przemysłowej, jak i takich, które wypełniaja zasady zrównoważonego rozwoju i cechują się tym, że:

- będa zawierały inteligentne materiały adaptujące się do różnych warunków przez zmianę właściwości, takie jak: dynamika, wielkość, kształt, zachowanie pod wpływem ciepła;

- liczba różnych materiałów w każdym produkcie będzie zredukowana do minimum;

- nanomateriały będa powszechnie stosowane do nakładania powłok na różne produkty, mających specjalne właściwości, takie jak: samoczyszczenie, antyodblask, niebrudzenie; 
- $\quad$ większość produktów będzie zawierać części używane, ponownie wykorzystane do produkcji.

Podobnie:

- $\quad$ powszechne stanie się zintegrowane, sustensywne zarządzanie;

- powszechna stanie się rozszerzona odpowiedzialność producenta;

- $\quad$ wszystkie przedsiębiorstwa będą odbierały swoje zużyte produkty i będą dbały o ich utylizację;

- etykiety elektroniczne, zawierajace istotne informacje o produkcie i procesie, będą umieszczone na większości produkowanych wyrobów;

- funkcjonalność złożonych produktów głównie będzie osiagana dzięki oprogramowaniu lub adaptacji elektronicznych komponentów;

- normą będa produkty wysokiej jakości, sprzedawane oraz kontrolowane za pomocą funkcji samodiagnostyki, a także montowane i konserwowane samodzielnie.

\section{Podsumowanie - na autostradzie do mobilnego miasta}

Druga dekada dwudziestego pierwszego wieku cechuje się obecnością metafor zawierających w swej treści cyfrę cztery, zarówno jako rewolucja pržmystowa 4.0, jak i kapitalizm 4.0 [Kaletsky, 2010a; 2010b]. Z kolei, czwarta rewolucja przemysłowa, oznaczająca działania podmiotów gospodarczych dzięki bezprzewodowym i przewodowym komunikacyjnym połaczeniom jednoznacznie zaadresowanych do wielu mobilnych i stacjonarnych inteligentnych urządzeń łącznie realizujących i materializujących fizyczny produkt, wiąże się z gwałtownym wzrostem efektywności: surowcowej, logistycznej i transportowej. Pojawienie się koncepcji rozwoju sustensywnego było silnym impulsem do pojawienia się wielu inicjatyw, których celem była i jest poprawa jakości życia w mieście. Wszystko to wpisuje się w kwestie spójności: społecznej, gospodarczej i terytorialnej oraz zrównoważonego i odpowiedzialnego rozwoju, współtworząc ramy polityki spójności lat 2014-2020.

Niektóre determinanty zmian jakości życia przedstawione w pracy, obrazuja jednocześnie wielowymiarowy charakter rozumienia zwiększania jakości życia w mieście, jak i pokazują, w ramach trwającego dyskursu dotyczącego miast przyszłości, miast idealnych czy miast zrównoważonych - mobilnej koncepcji kształtowania współczesnego miasta. Uwzględniane jest to w kontekście obecnego etapu rozwoju cywilizacji, wdrażania koncepcji zrównoważonego oraz mobilnej produktywności, jak również wdrażanej w Polsce Strategii odpowiedzialnego rozwoju [Strategia odpowiedzialnego rozwoju, 2016].

W roku 2016 ludzkość znalazła się już na autostradzie, która prowadzi wprost do miast mobilnej produktywności w Polsce. Pojawili się konsumenci 4.0 [Janikowski, 2016], a że jest to prawda, niech świadczą te słowa: ponad 90 proc. Polaków zadeklarowało, $i \dot{z}$ aktywnie korzysta zurzqdzeńn mobilnych w przygotowaniach do Bożego Narodzenia. Najczéściej przed świetami poszukujemy w sieci przepisów kulinarnych (27 proc.), inspiracji na dekoracje domu (24 proc.) oraz życzeń śmiatecznych $i$ koled (20 proc.). Internet oraz urzadzenia mobilne zdominowaty nie tylko 
codzienne s̀ycie Polaków, ale również okres praygotowania do świat - takie wnioski plyna z sondy zrealizowanej przez serwis „Prezent marzeñ” wśród 4162 Polaków [http:/ /www.polskaszeroko pasmowa.pl/trendy/technologia-i-internet-pomagaja-przygotowac-sie-do-swiat.html].

Podobnie dokumentuja ten fakt inne słowa: $W$ ramach inwestygi zwiqzanej z budowa Ślaskiej Regionalnej Sieci Szkieletowej powstała infrastruktura swiattowodowa o dtugości ok. $457 \mathrm{~km}$. Specyfika szerokopasmowego projektu w tym województwie byto to, że sieć sktada sie z.dwóch oddzielnych cześci: pótnocnej o dtugości $252 \mathrm{~km}$ i potudniowej, która licsy $205 \mathrm{~km}$. Cześć pótnocna taczy m.in.: Tarnowskie Góry, Lubliniec, Ktobuck, Czestochowe, Myszków, Zawiercie, Dabrowe Górnicza i Sosnowiec. W zasiegu cześci poludniowej znajduja sie m.in.: Tychy, Pszrçyna, Bielsko-Biała, Żywiec, Żory, Jastrzebie-Zdrój, Cieszyn, Wodzistaw Ślaski, Rybnik i Racibórz. [http://www.polskaszerokopasmowa.pl/inwestycje/slaska-regionalna-siec-szkieleto wa-gotowa-do-swiadczenia-uslug.html (data wejścia: 03.03.2017)]. Jednocześnie należy pamiętać, że całkowita wartość projektu budowy Ślaskiej Regionalnej Sieci Szkieletowej wyniosła 58,8 mln zł, z czego 85\% stanowiły środki unijne z Regionalnego Programu Operacyjnego Województwa Śląskiego na lata 2007-2013.

\section{Literatura}

A Future That Works: Automation, Employment, And Productivity, 2017, McKinsey Global Institute (MGI), San Francisco.

Cities of tomorrow. Challenges, visions, ways forward, 2011, European Union, Brussels.

INDUSTRIE 4.0 Smart Manufacturing for the Future, 2014, Germany Trade \& Invest, Berlin.

INDUSTRY 4.0. The new industrial revolution. How Europe will succeed, 2014, Roland Berger Strategy Consultants Gmbh, Munich.

Janikowski R., 2013, Sustensywne doskonalenie przestrzeni publicznej miasta, [w:] Gospodarka regionalna i lokalna a rozwój zrónnoważony, Z. Strzelecki, P. Legutko-Kobus (red.), Studia t. CLII, Komitet Przestrzennego Zagospodarowania Kraju PAN, Warszawa.

Janikowski R., 2015, Zarzadzanie przedsiebiorstwem 4.0. Problemy badawcze, [w:] Strategie w zarzadzaniu organizacjami, J. Rokita (red.), Wydawnictwo Górnośląskiej Wyższej Szkoły Handlowowej, Katowice.

Janikowski R., 2016, Przedsiebiorstwo 4.0 i jego klienci, [w:] Kompetencje - modele biznesu strategie, J. Rokita (red.), Wydawnictwo Górnośląskiej Wyższej Szkoły Handlowej, Katowice.

Kaletsky A., 2010a, Capitalism 4.0: The Birth of a New Economy in the Aftermath of Crisis, Public Affairs, Bloomsbury, London.

Kaletsky A., 2010b, Capitalism 4.0, OECD Observer, no. 279, May.

Kleiber M., Kleer J., Wierzbicki A.P., Galwas B., Kuźnicki L., Sadowski Z., Strzelecki Z., 2011, Raport Polska 2050, Polska Akademia Nauk - Komitet Prognoz „Polska 2000 Plus", Warszawa.

Komunikat w sprawie prazysztości sieci i internetu, 2008, Komunikat Komisji Europejskiej do Parlamentu Europejskiego, Rady, Europejskiego Komitetu Ekonomiczno-Społecznego oraz Komitetu Regionów, 594, wersja ostateczna. 
Konin 2050, 2015, Jaka przysz̨łość czeke Konin?, Foresight Miejski, Pracownia Miejska i Format Project, Konin.

Miasta przyszłłósi. Wyzwania, wizje, perspektywy, 2011, Unia Europejska. Polityka Regionalna, Bruxelles.

Paszkowski Z., 2011, Miasto idealne w perspektywie europejskiej i jego zwiqzki z urbanistyk.q wspótcresna, UNIVERSITAS, Kraków.

Recommendations for implementing the strategic initiative INDUSTRIE 4.0, 2013, Securing the Future of German Manufacturing Industry, Final Report of the Industrie 4.0 Working Group, Acatech National Academy of Science and Engineering, Berlin.

Ritzer G., 2001, Magiczny swiat konsumpcji, Warszawskie Wydawnictwo Literackie MUZA, Warszawa.

Scharmer O., Kaufer K., 2013, Leading from the Emerging Future: From Ego-System to EcoSystem, Berrett Koehler, San Francisco.

Schwab K., 2016, The Fourth Industrial Revolution, World Economic Forum, Geneva.

Strategia odpowiedzialnego rozwoju, 2016, Ministerstwo Rozwoju, Warszawa. 